\title{
Establishing Evaluation Criteria of Modern Heritage Conservation in Historic City Centers in Jordan
}

\author{
Maisa Ali Al-Shomali
}

\begin{abstract}
In the last few decades in Jordan, several rehabilitation projects were established in heritage cities as tourism developing projects, (such as As-Salt city) with international funding support. These projects are concerned with conservation of historical buildings. The current paper highlights the hidden aspects of these projects; which mainly neglect Modern Heritage buildings focusing on older historical sites. The paper focuses on As-Salt city as a case study where significant buildings are not recognized as Modern Heritage, although they played an important role in the city's life including commercial buildings and one school, dating back to 1961, and were demolished. This study investigates the important values and the role of some of these buildings within their urban context, including the effect of their loss on the local community; socially, functionally and economically. It suggests some evaluation criteria as a frame work to determine Modern Heritage buildings that need to be conserved. The study uses both quantitative and qualitative analysis. 200 structured interviews were conducted to address the impact of demolition and to reach a conclusion about the other unaccountable effects. The study shows that the demolition of Modern Heritage buildings had negative effects on the local community, due to their important role in the collective memory of the city. The study recommends developing a Jordanian rating system for evaluating, listing, classifying, and protecting Modern Heritage buildings.
\end{abstract}

Index Terms-Modern Heritage building, urban conservation, heritage site planning, memory of the city.

\section{INTRODUCTION}

In conservation practice, building age has traditionaly been the main factor considered in conservation classification. Nowadays, with the development of conservation theories, many other factors have been added to classify hearitage site values [1].

Professor Judi Loach has been a major critic of the neglect of modern heritage buildings in conservation process. In 2009 he declared that in order to avoid blaming ourselves in the future, we should not repeat the same mistakes in neglecting conservation of heritage buildings [2].

Likewise Grementieri (2003) states that "It is important to send out warnings about those pieces which have not been completely studied or analysed for diverse reasons and which could quickly become very valuable heritage" [3].

Important buildings of modern heritage represent the future heritage, city history, and the political periods that a city has passed through. In addition, important buildings represent an important part of the urban fabric that defines

Manuscript received February 18, 2020; revised October 15, 2020.

The author is with Architecture Department, Al-Balqa Applied University, Salt city, Jordan (e-mail: m_alshomali@bau.edu.jo). spaces, and links places with communi ty memory.

Traditionally due to tourism revenues, in Third World countries, the focus has been on preserving historic buildings that have not yet received enough attention. Thus, there is little interest in preserving modern heritage buildings.

This study investigates the important values and the role of some of these buildings within their urban context, and the effect of their loss on the local community; socially, functionally and economically. It suggests an evaluation criteria as a framework to determine Modern Heritage buildings that need to be conserved.

The study uses both quantitative and qualitative analysis. 200 structured interviews were conducted with different kinds of related people; shop owns, student's parents, school teachers, the school manager, alumni, and many others, to understand the impact of demolition and to reach a conclusion about the other intangible effects on the community.

\section{Modern Heritage Issue}

In order to shed light on the Modern heritage story, how it started and became recognized by international organizations, below are some milestones in conservation:

In the late $1980^{\mathrm{s}}$ and early $1990^{\mathrm{s}}$ new conservation challenges emerged as seminal architectural works of the Modern Movement reached fifty years of age thereby becoming eligible for heritage protection. Modern Heritage came to represent an important part of the urban space and visual architectural landmarks that define spaces and associated with the collective memory of a city.

It is worth challenging ourselves to recognize our Modern Heritage not only for the balance of our appreciation of different cultures, but also in order to generate self-esteem and pride in this period of globalization when important values tend to be forgotten and ignored. The World Heritage Centre at UNESCO has taken an active role in the promotion of consciousness of recent heritage. There is still, however, a long way to go both in understanding what our Modern Heritage is, and secondly in providing the necessary means for its protection and appropriate conservation management [4].

To address the lack of practical conservation knowledge, the Getty Conservation Institute convened a colloquium of experts in the field in March 2013. (Kuipers, 2003) [5]. "In the ICOMOS worldwide Survey, a significant number of the case studies on 20th century heritage evidence that the concept of the Modern Heritage has been expanded from the exclusive concept of the material culture to the intangible aspects of heritage including industrial heritage, education, 
cultural landscape, planning, and community life" [6].

A. International Organizations and Approaches to Modern Heritage Conservation.

The organization DOCOMOMO ${ }^{1}$ [7], was founded in 1988 by the Dutch Hubert Hanki and Wessel de Jonge in Eindhoven. The purpose of this organization was to take care of modern heritage architecture that had been turned into an international movement.

DOCOMOMO was headed by Mees Van Deroh as general of the secretary. It was the founding stone of an international conference where people and architects from all over the world who were intrested in conserving modern heritage met every two years to share their knowledge and experience [8].

In 2001 both the UNESCO World Heritage Centre and the World Council of Monuments and Sites ICOMOS and DOCOMOMO, established a joint program aimed to define, document, and to preserve modern heritage architecture of the nineteenth and twentieth centuries under the name of "Program of Modern Heritage" [9].

ImAAN (Modern Asian Architecture Network) and the Council of Europe have conducted studies on the documentation and conservation of the Modern Heritage since the 1990s In 1991 a new proposal was presented within the scope of Modern Heritage suggestingthat all mass production products, public spaces, large settlements and new cities should be evaluated within modern architecture [10].

Also The Getty Conservation Institute (GCI) is dedicated to the presentation, conservation, and interpretation of the world's artistic legacy. "Ge 'tty Foundation" awards grants for the understanding and preservation of the visual arts, held conferences in order to let various thinkers talk and write about the importance of conserving the modern heritage val777 uable architecture, and issued a number of magazines specialized on this issue [11]. The ICOMOS International Scientific Committee on Twentieth-Century Heritage began activity in the early $2000^{\mathrm{s}}$, launching Heritage Alerts, a program advocating for threatened and significant twentieth-century places.

In 2011 ICOMOS adopted the Madrid Document: Approaches for the Conservation of Twentieth-Century Architectural Heritage ${ }^{3}$ [12]. Other organizations have also been working in a variety of ways to advance this area of conservation [13].

Consequently, global organizations, institutions and academia who were interested in modern heritage architecture held regional meetings and international conferences in various countries to get charters and recommendations to: identify [14] and maintain modern heritage buildings and sites that were built during the last two decades; to determine values that make modern and historical buildings have the same importance; to develop plans and

\footnotetext{
1 International Committee for Documentation and Conservation of Buildings, Sites and Neighborhoods of the Modern Movement.

2 "Getty Grant Program", which began in 1984, under the direction of Deborah Marrow, interested in conservators and art museums.

${ }^{3}$ ICOMOS International Scientific Committee on Twentieth-Century Heritage, Madrid Document: Approaches for the Conservation of Twentieth-Century Architectural Heritage, 2011. http://www.icomos-isc20c.org/madrid-document/.
}

framework, and to prevent the demolition of valued buildings which belong to the modern period, regardless of their age [15].

The conclusion of the above mentioned activities was that the World Heritage Center began to place Modern Heritage sites within the World Heritage List wich added international interest [16].

\section{B. Modern Heritage Evaluation Criteria}

The values of architectural Modern Heritage have not yet been clearly ditinguished from the values of ancient architectural heritage. As imphasized by Jokilehto, (2006), evaluation criteria must apply to all kinds of cultural heritage, including Palaeolithic archaeological sites, Monuments of Antiquity, Medieval historic towns, as well as to monuments, groups of buildings or sites representing Modern Heritage [4].

Various values are now included in evaluation; such as social, cultural, architectural, aesthetic and scientific. To consider the importance of the modern buildings [17], in order to identify, register and classify Modern Heritage. Indeed, Jokilehto mentioned that all judgments about values attributed to cultural properties as well as the credibility of related information sources may differ from culture to culture, and even within the same culture. It is thus not possible to base judgments of values and authenticity within fixed criteria. On the contrary, the respect due to all cultures requires that heritage properties must be considered and judged within cultural contexts to which they belong.

This is particularly the case in Asia, where different and sometimes antagonistic traditions in heritage conservation coexist [18]. Some countries have established criteria for evaluating their modern buildings, to determine Modern Heritage, and classify them according to their importance.

According to Francesco Bandarin, the Director of UNESCO World Heritage Centre [19], On the World Heritage List of May 2003, only 12 sites represent Modern Heritage of the 19th and 20th centuries out of a total of 730 listed properties and sites. To be included on the World Heritage List for the Modern Heritage Program, sites must be of outstanding universal value and meet at least one out of ten selection criteria.

The Operational Guidelines elaborate on the criteria required for the definition of the outstanding universal value of the nominated property. They were initially six criteria for cultural properties and four for natural. Resulting from the recommendation of the 1998 expert meeting at Amsterdam, the World Heritage Committee decided to join these criteria, forming a list of ten, published in the 2005 edition of the Operational Guidelines. In essence, the cultural criteria refer to a property as a representation of: i) a masterpiece of human creativity, ii) important exchange of values (influences), iii) a unique or exceptional testimony to a tradition or civilization, iv) an outstanding example of a type of building, ensemble or landscape, v) an outstanding example of a traditional human settlement or land-use, vi) direct or tangible association withevents or living traditions, ideas or beliefs. The criteria from vii) to (x) refer to natural heritage [20].

\section{Examples of Evaluation Criteria}


As there is no recognition of Modern Heritage in Jordan, therefor, this study will review some evaluation criteria used in different international and regional countries. Recognition of a site's heritage values is a continuous and open-ended process, that deepens as society develops and its scientific and cultural awareness increases. [21].

TABLE I: THE CRITERIA USED IN TURKEY FOR MODERN HERITAGE

\begin{tabular}{|c|c|c|c|c|c|}
\hline Value & $\begin{array}{c}\text { Spatial \& } \\
\text { Architectural } \\
\text { values }\end{array}$ & Functional value & $\begin{array}{l}\text { Modern language and } \\
\text { materials }\end{array}$ & Social value & Continuity Use value \\
\hline Indicator & $\begin{array}{l}\text { - Location } \\
\text { - Topography } \\
\text { - Human scale } \\
\text { - Landscape }\end{array}$ & $\begin{array}{l}\text { - The structures that can } \\
\text { sustain their original } \\
\text { function are the most } \\
\text { important } \\
\text { representatives of } \\
\text { Continuity value. } \\
\text { - Keep the heritage alive } \\
\text { by using } \\
\text { Memorial value for } \\
\text { some functions. }\end{array}$ & $\begin{array}{l}\text { - Using concrete and new } \\
\text { materials. } \\
\text { - Using Modern } \\
\text { architectural language. }\end{array}$ & $\begin{array}{l}\text { - The collective } \\
\text { memory of the } \\
\text { heritage site can be } \\
\text { preserved, reused and } \\
\text { given an extension of } \\
\text { its life by adaptive } \\
\text { reuse. } \\
\text { - Gathering place. } \\
\text { Large scale of users. } \\
\text { Emotional value }\end{array}$ & $\begin{array}{l}\text { - The continued use of a } \\
\text { cultural heritage. } \\
\text { - Determination of a } \\
\text { proper place in } \\
\text { contemporary society. } \\
\text { - Using the structure } \\
\text { itself will be provided a } \\
\text { statement. } \\
\text { - Defined as "A future for } \\
\text { our past" }\end{array}$ \\
\hline
\end{tabular}

In the assessment system, indicators vary between countries according local priorities, some countries determine artistic, historical and scientific values, followed by more significant values including environmental, cultural/ emotional and real estate values, like China [22]. While Duch criteria determine different values like: Beauty, Cultural heritage, Science, Recognizability, Rarity, Spatial Context, Condition, and Authenticity/ Integrity [23] ${ }^{4}$.

This study adopted some of the Turkish framework in "Modern Heritage"conservation criterim, that regional conservation councils have taken many decisions to set the grounds for conservation, within the scope of the architectural, functional and social dimensions, it is necessary to define new values besides the values of old, aesthetic and historical documents. [24].

What is to be conserved or what is to be demolished cannot be discussed in a purely professional way independently of contextual data, to reveal and sustain the spatial and social meaning of the structures. It is possible to determine the values and investigate them under the groups shown in Table I [25].

\section{LITERATURE REVIEW}

Zanchet (1997) indicates that the "Value" concept had developed through a long evolution of human thought including historical, artistic, social, political, educational, cultural and many others. However such various dimentions of values have become beyond the discussion and analysis of projects on modern heritage buildings [26].

After reviewing criteria examples from different countries, it is important to review literature about special values connected with conservation in Jordan, to benefit from those criteria of other countries and cover the whole needed values in Jordan. These values are related to the relationship between place and community, people's memory in the city and their involvement in taking decisions about their city.

\section{A. Value of Place}

Getty Foundation publication series mentiones that public participation is one of the main tools to make people aware of

\footnotetext{
${ }^{4}$ Architecture Professor, Delft, the Netherlands.
}

the place value. The values of each place should be the focus of the preservation process. The Australia ICOMOS Burra Charter was the first among UN researchers to discuss the concept of the place and its value in historical sites [26].

The concept of "Place", as stated in Burra Charter is valuable in understanding Modern Heritage, and indeed all heritage in a modern context. [27]

\section{B. Buildings Demolition and City Memory}

Ruskin (1989) considered the city as a historical accumulation of different civilizations, with multiple periods and different eras and tastes. Ruskin called to reject the methods of restoration that aimed to unify the architectural style, and to conserve one era style while neglecting others [28].

Lynch focused on the perception image in human minds through living in urban places and it's landmarks for long periods. He suggested to take into consideration people's activities and their interaction with their memories in the city's urban spaces and it's physical elements [29].

Abu al-Hija (2011) considered modern building demolition in heritage centers a lack of respecting these buildings and the multiplicity of architectural languages and eras. This leads to erasing local community memory from city's history and elements [30].

\section{Public Participation in Heritage Conservation}

Several studies have investigated the importance of public participation in the development of heritage sites. This issue has been the subject of multiple studies such as Khirfan, Luna, and Basma Momani (2011) [31]. These studies confirm the importance of local participation especially in the developing countries where heritage tourism is an important economic resource. They emphasize that sustainable development could be achieved through the participation of the community in the planning and implementation [32].

Tiesdell (2001) considered that it is important to take into account the economic empowerment during the conservation of historical areas and heritage sites. This would lead to enable residents and owners to maintain their sites through the development of the economic conditions and of creating jobs [33].

Daher (1999) indicated that rather than emphasizing beautification as a central goal of the maintenance, it is also 
of equal importance to emphasize public participation and cooporation in such projects. Such participation would ensure the achievement of sustainable development [34]. His study also indicated the importance of raising awareness of participation in decision making and to motivate them to be part of maintaining historical sites. Effective participation could be achieved by the capacity of project administater in training the community to maintain such restoration; such training would lead to real benefit of preservation process.

Internationally, evaluating products of modern architecture as cultural heritage has been among the basic issues within the conservation theory and practices of Western countries since the $1980^{\mathrm{s}}$. Defining the scope and importance for this new component of heritage has been on the agenda of all parties internationally.

Locally in Jordan, Modern Heritage is not well considered except in rarely cases. Centre for the Study of the Built Environment CSBE in Jordan, recently published a study for important modern building that were lost by demolition in Amman, no specific criteria were determined for selecting these building, but as they mentioned, each building had its own importance based on its location, or architectural design, or the designer [35].

There is anxiety that these values are being destroyed. This anxiety is increasing as buildings which have high plot value due to their urban location or social impact are demolished and re-built by investors, or by local governments in order to beautify the city.

This Study will shed light on one of the case studies in Jordan for the first time, from As-Salt city that contained a demolition of modern heritage buildings within its urban development project.

\section{Establishing Modern HeRITAge Evaluation CRITERIA IN JORDAN}

This study suggests criteria and values for Jordan, by utilizing each of the included values in the literature review and international examples mentioned in section $\mathrm{C}$ above.

Conservation criteria have values and indicators that vary from country to country, these values can be summarized in "social, economic, cultural, spatial, architectural, functional and use". These values were invistegated in the interviews for the local community for selected buildings as a case study.

This study focuses on two buildings in As-Salt city, selected to apply the proposed criteria (Table II) to find out the most important values and indicators for the local community for Modern Heritage.

\section{As-Salt City Heritage Center — CAse Study}

\section{A. Context}

The Third Tourism Project is one of the most important conservation projects in Jordan. This project was established to develop five heritage city centers; Karak, Madaba, Ajloun, Jerash and As-Salt. As-Salt is one of the most important cities in Jordan. Its heritage center is distinguished by yellow lime carved stone buildings from the late Ottoman era mixed with many modern buildings with white stone (Fig. 1). This project started in 2006 to enhance tourism in Jordan, funded by the World Bank. Today, most stages of the project are completed [36].

Before the $1950^{\mathrm{s}}$, the triangular area of 15 acres which was developed by the Third Tourism Project used to be an orchard called "Abu Rassa. Orchard" (Fig. 2). After the $1950^{\text {s }}$, many commercial modern buildings with white stone were built in this area, inluding a school, a bank, restaurant, beauty salon, bakery, barber, supermarket and many other facilities and shops (Fig. 3). According to a study by the Royal Scientific Society in 1989, the Third Tourism Project in As-Salt city worked on developing an important triangular area in the middle of the heritage city center, (Fig. 4). One of it's components was demolishing all modern white stone building and Oqba bin Nafi school, while conserving the historical yellow buildings. Demolition was applied in 2007. Its purpose was to solve the problem of traffic jam, and to expose the hidden historical yellow stone buildings, and to eliminate the image of odd white stone buildings among the heritage area in the city center.

The new project aimed to replace the demolished area by a project that contains big yards as a public space, a few shops and services (Fig. 5) [37].

This study will invistigate the importance and values of two of these modern demolished buildings; Al-Khayyam Restaurant, and Oqba bin Nafe School.

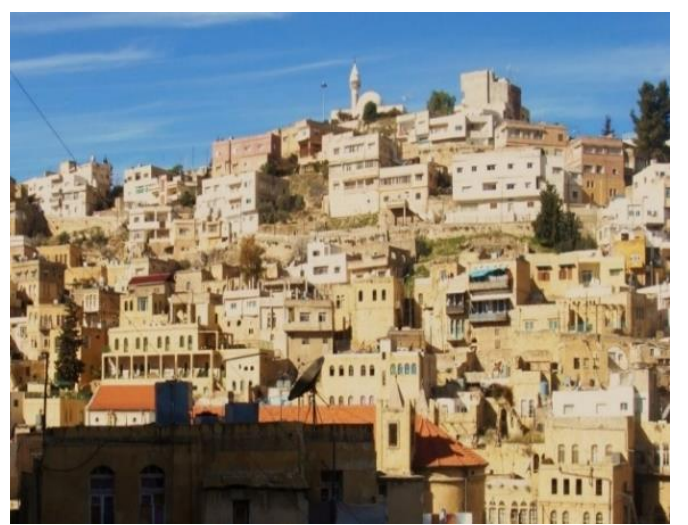

Fig. 1. As-Salt city centre with its distinguished yellow stone buildings. Source: Author, 2012.

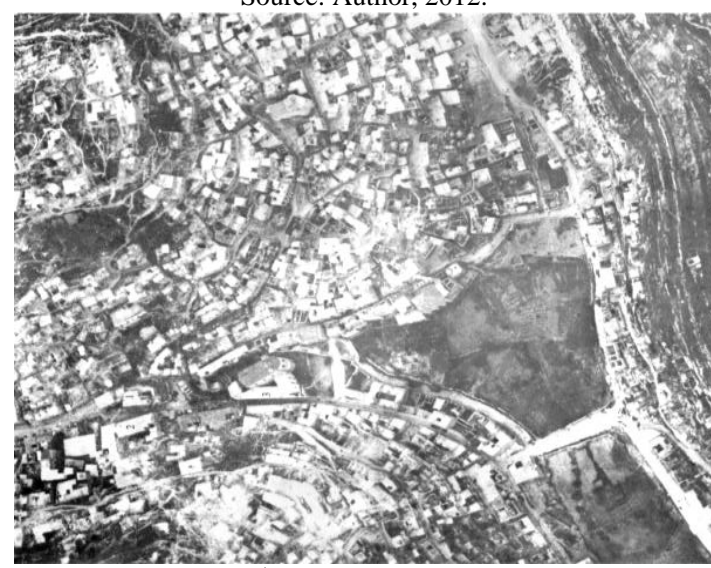

Fig. 2. Arial view from the $1^{\text {st }}$ World War, shows the orchard triangular area, 1917. Source: German Army Archive.

\section{B. Al-Khayyam Restaurant}

People from other cities used to visit Al-Khayyam Restaurant in As Salt city, which belongs to Mr. Omar Al 
Khayyam (Fig. 6). The restaurant was known in serving the famous "Shish Kebab" since 1952. The shop was rented and located in a vital location, near Oqba bin Nafi school in the commercial area in the middle of downtown, many other shops and civil associations were renting in these same buildings which were demolished.
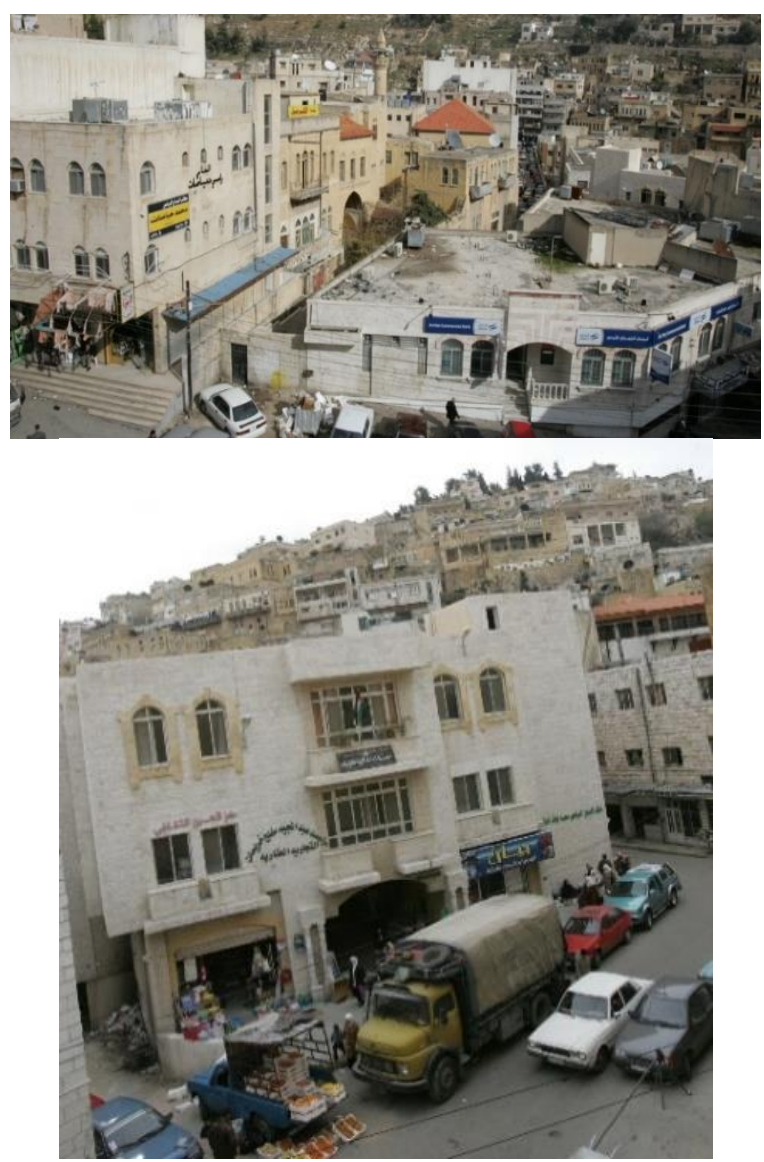

Fig. 3. Modern white demolished buildings. Source: Author, 2007.

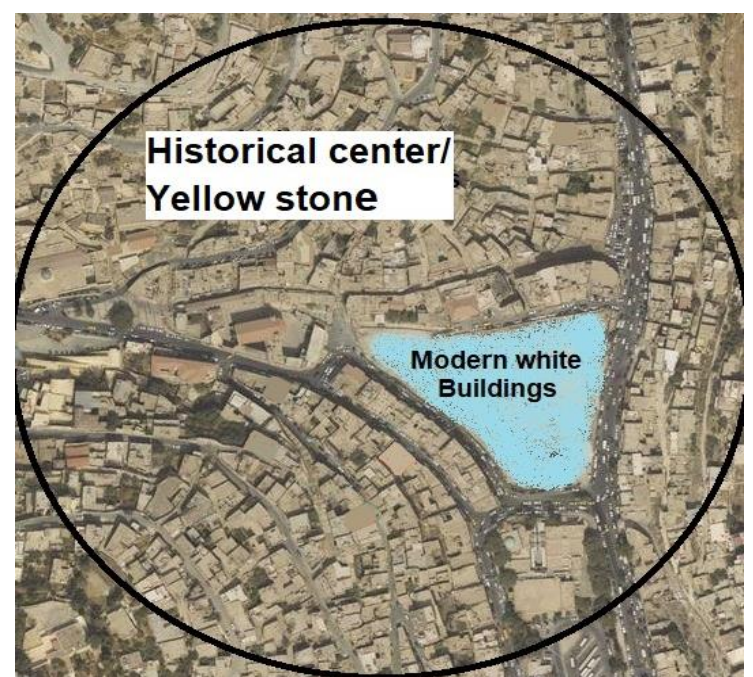

Fig. 4. Arial view for the triangular modern area, surrounded by yellow historical buildings in the city centre. Source: Google Earth, modified by author, 2019.

\section{Oqba Bin Nafe School}

A three story building school was built on the triangular area over 7 acres' land at the end of $1950^{\varsigma}$, surrounded by streets that led to an active area in the heritage city centre (Fig. 7).

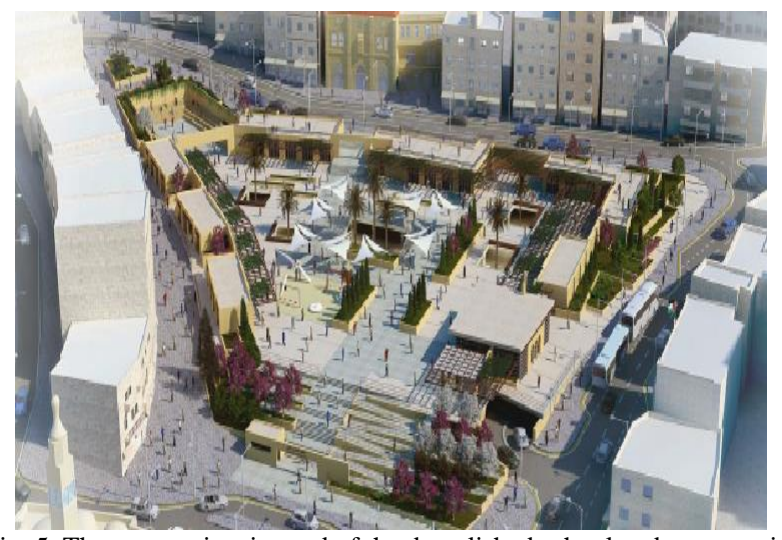

Fig. 5. The new project instead of the demolished school and commercial buildings. Source: As-Salt Municipality, 2019.

The school had 1000 students. It served a large part of the local community for its easy access from different neighbourhoods, either walking or by using public transportation. The school's famous 350 sq.m playground area was used as the city's only playground for the youth, and as an open space, located in the city centre.

Football matches were conducted in the playground for the whole city youth. The only theatre in the city was the main school hall; most of the city social and entertainment activities between $1960^{\mathrm{s}}-1980^{\mathrm{s}}$ were conducted in that hall. Many great local personalities like Samira Tewfik performed on its theatre.

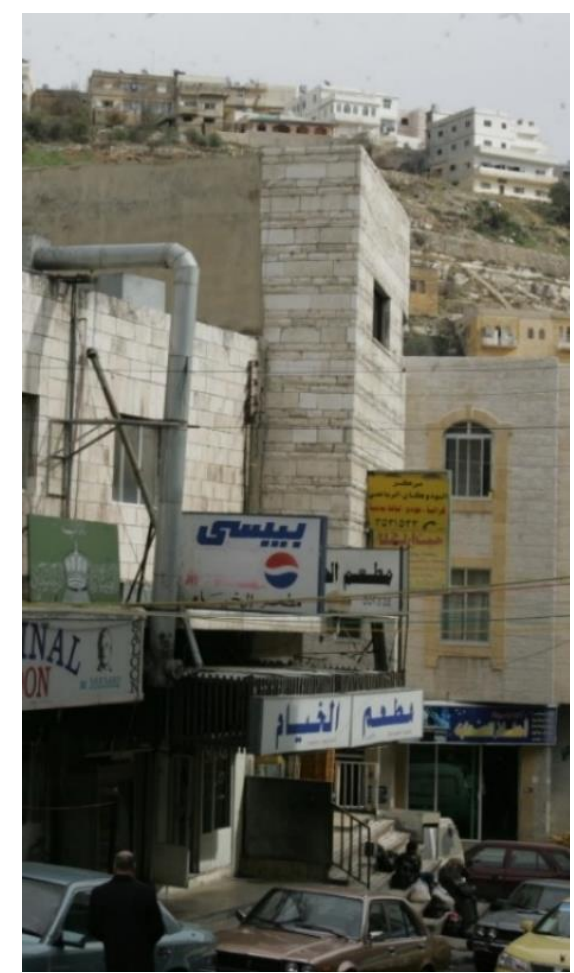

Fig. 6. Al Khayyam Restaurant within commercial modern buildings. Source: Author, 2007.

The architectural language of the school buildings adopted the International Style which was popular at that time (Fig. 8). White stone with concrete buildings, horizontal openings, clear structural system showing the module, columns and the slabs, all of these characteristics were clear expressions of the modern style (Fig. 9).

It is worth mentioning that modern buildings in Jordan were built in the fifties and sixties from the last century, the 
architectural launguage of these buildings has been developed from the late Ottman period towards modernity, they had a hybrid language joining between the two languages, not pure Modern Architecture style.

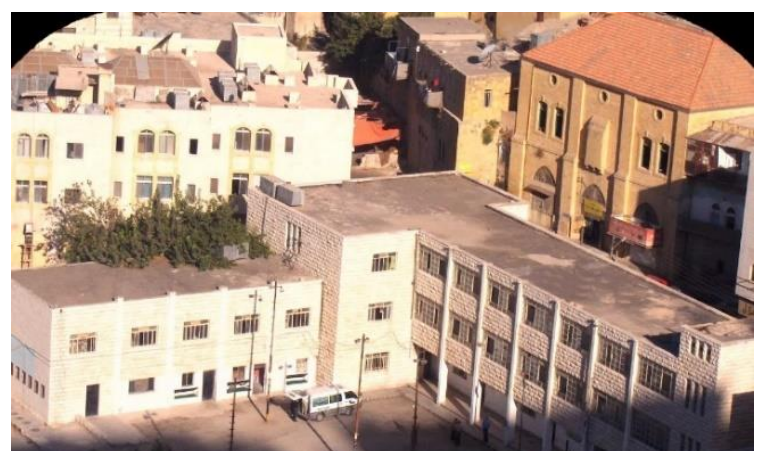

Fig. 7. The school; modern architectural language within a historical urban surrounding.

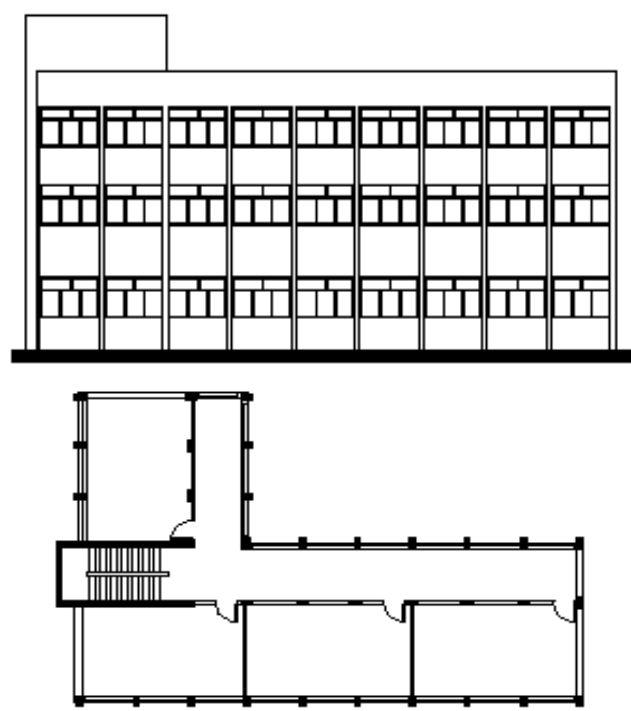

Fig. 8. School building plan and elevation; with modern architectural language; see the horizontal openings and the module structure. Source: Author, 2019.

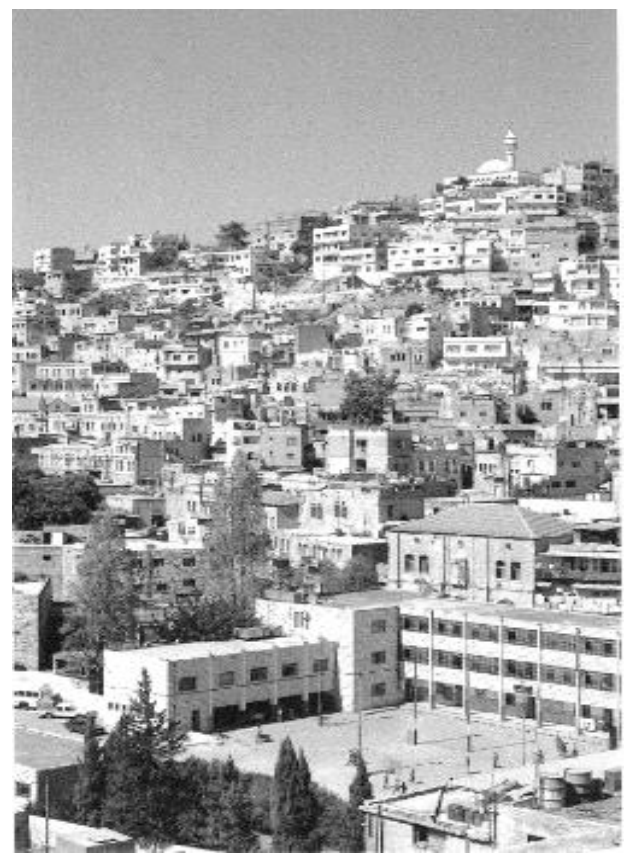

Fig. 9: The school; modern architectural language within a historical context, the biggest playground in the city. Source: The Royal Scientific Society, 1990.

\section{RESEARCH QUESTIONS}

The study tries to explore the questions outlined below about the Modern Heritage buildings:

- What values and importance did the demolished buildings have during their life?

- Was there a procedure or a study on the building's importance before taking the demolition decision?

- What are the social and economic impacts of the demolition on the local community?

- What is the satisfaction level about buildings demolition from the local community?

- Do developing countries recognize Modern Heritage, "Jordan as a model"?

- Are there criteria and values to determine Modern Heritage in Jordan?

\section{RESEARCH METHODOLOGY}

The study used both qualitative and quantitative analysis. The used anthropological method included interviews and data collection. 200 structured interviews were conducted on several categories of As-Salt city community; parents, merchants, employees, teachers, etc, to address the impact of demolition on the purchasing power and the functional service in the area, and to reach a conclusion about the other intangible effects.Also the study measures the amount of public satisfaction and participation in this sensitive project.

To join between theoretical and applied study for this research, literature about value and role of place, city memory, public particippation are reviewed.

The importance of this study lies in that it defines a framework and sets a criteria to evaluate the Modern Heritage buildings in Jordan, in order to have important decisions in conserving them and stop random demolition desicions.

It was clear through the interviews that some of the demolished buildings had special importance for the local community because of their role and values. This was revealed by discussing their values and the impact of their loss on the local community. The study tries to measure the community's satisfaction of building demolition.

This study will set a criteria to evaluate Modern Heritage according to: a) the literature review, b) reviewed examples, c) the findings of the interviews, taking in to consideration the most important values of the Jordanian community, to determine and recognize the Modern Heritage in Jordan and the developing countries, so as to develop regulations to protect the existing Modern Heritage building.

\section{FIELD WORK AND DATA COLLECTION}

In order to address the values of the demolished buildings, and the impact of the demolition on the local community economicaly, functionaly, socialy and emotionaly, the amount of public satisfaction and participation in this sensitive project is invstigated, two hundred structured interviews were conducted to the people associated with the site, including shop owners, the last director of the school and many of its staff, destrict educational director, alumni, alumni 
parents, shoppers around the school.

\section{A. Discussion about the Demolished Buildings}

1) Why to discuss a demolished building?

Most of developing and touristic projects in Jordan and the region, havng their contents "Building's", in order to creat yards or rebuild other facilities. Demolition dicision is easy to be taken,no instructions or caveats control it.

Unfortunately, in the absence of a system and criteria to evaluate their values Jordan has lost many of it's Modern Heritage buildings by demolition [36]. People protested against important building's demolition, shoppers around the school.

It was the demolition of As-Salt buildings that set the alarm bell off for the need to be careful not to lose more important buildings. In the absence of recognition of the Modern Heritage, and the absance of evaluation system for their values, Jordan has unfortunately lost many of Modern Heritage.

2) What are the values of the demolished buildings?

- Al-Khayyam Restaurant

The interviews conducted showed the importance of “Al-Khayyam Restaurant” [38][-41] (Fig. 6). Unfortunately, the procedures were not fair for the restaurant owner in the payment of the acquisition compensation, most of the financial compensation went to the owner of the building, while the restaurant owner get little amount of the money. The municipality of As-Salt offered a new shop for the restaurant in another place in the new project yard. The restaurant lost its traditional place and lost a lot of its clients. Its important for any development project to empower Economy in the heritage areas. Demolishing the restaurant building and moving its location had absolutely a bad affect on the restaurant. People deal with the restaurant in its new location as a new restaurant. It lost its long history associated with the place.

\section{- Oqba bin Nafi School}

The famous popular school was built in 1961 and demolished in 2007, from the questionnairs and the interviews from [38]-[41], it was clear that the school had special importance for the community. It had many roles in their life.

It was noted that the phrase "It is not a development, it is a destruction" for the developing project, has been repeated many times from the local community. Residents and alumni refused the demolition, they considered that the school as part of their youth memory during their study, recreation, social life, and playing football matches.

The quantitative analysis show the results demonstrated in Table III.

TABLE II: AL-KHAYYAM RESTAURANT VALUES. SOURCE: AUTHOR 2019

\begin{tabular}{|c|c|c|}
\hline \multicolumn{2}{|l|}{ Values } & Indicator \\
\hline Cultural & Public Food & $\begin{array}{l}\text { Al-Khayyam Restaurant served } \\
\text { the public Sheish Kebab, in a } \\
\text { traditional cooking way, }\end{array}$ \\
\hline Political & Political events & - \\
\hline Economic & $\begin{array}{l}\text { purchasing } \\
\text { power }\end{array}$ & $\begin{array}{l}\text { It was an intended commodity } \\
\text { that people came from several } \\
\text { places, economic value is an } \\
\text { added value to the area. }\end{array}$ \\
\hline Functional & Use Value & It had a specific function that it \\
\hline
\end{tabular}

\begin{tabular}{|l|l|l|}
\hline & & sold a special kind of food. \\
\hline Socially & Collective & $\begin{array}{l}\text { The restaurant had special } \\
\text { importance for the local } \\
\text { community that created a } \\
\text { collective memory for them, } \\
\text { related with the place and the } \\
\text { food. }\end{array}$ \\
\hline Emotional & $\begin{array}{l}\text { Sentimental } \\
\text { value }\end{array}$ & $\begin{array}{l}\text { Emotional relationship: During } \\
\text { the interviews, it was } \\
\text { noticedthat the place it self had } \\
\text { a special complecated value for } \\
\text { people, they were related with a } \\
\text { specific place with a specific } \\
\text { food. }\end{array}$ \\
\hline Architectural & Language & $\begin{array}{l}\text { The restaurant was located in } \\
\text { the ground floor of a two floors } \\
\text { simple white stone building, } \\
\text { with horizontal opennings, as it } \\
\text { was common in the fifties as } \\
\text { modern architectural era. }\end{array}$ \\
\hline Spatial & Central location & $\begin{array}{l}\text { The restaurant was located in } \\
\text { the centre of the city within a } \\
\text { commercial area, and close to a } \\
\text { school, it served a large part of } \\
\text { local community. }\end{array}$ \\
\hline $\begin{array}{l}\text { Spirit of the } \\
\text { place }\end{array}$ & $\begin{array}{l}\text { A special relationship between } \\
\text { the function and the place. } \\
\text { When the municipality replaced } \\
\text { the location of the same } \\
\text { restaurant, people lost their } \\
\text { passionin in the restaurant.This } \\
\text { is another added value "spirit of } \\
\text { place - Genious locai" }\end{array}$ \\
\hline
\end{tabular}

TABLE III: OQBA BIN NAFE SCHOOL VALUES. SOURCE: AUTHOR, 2019

\begin{tabular}{|l|l|l|}
\hline Values & $\begin{array}{l}\text { Cultural } \\
\text { events }\end{array}$ & $\begin{array}{l}\text { Indicator } \\
\text { Both the interviews and the questionnair } \\
\text { show that the school was a significant place } \\
\text { for the community used their cultural } \\
\text { activities, match games, theater plays, } \\
\text { galleries, and many others. That the school } \\
\text { had the only theatre and the only playing } \\
\text { yard in the city at that time. }\end{array}$ \\
\hline Political & $\begin{array}{l}\text { Political } \\
\text { events }\end{array}$ & $\begin{array}{l}\text { It was a remembered day when the late } \\
\text { King Hussain met the community and had a } \\
\text { speech from the school manager balcony to } \\
\text { the people in the yard. Many other political } \\
\text { events were conducted in the school, which } \\
\text { gave the school a political value. }\end{array}$ \\
\hline Economic & $\begin{array}{l}\text { Purchasing } \\
\text { Power }\end{array}$ & $\begin{array}{l}\text { The questionnaire shows that about 62\% of } \\
\text { the shop owners said that the buildings } \\
\text { demolition had negatively affected them in } \\
\text { weakening the purchasing power. The } \\
\text { school had around 1000 student as } \\
\text { customers, whichused to enhance the } \\
\text { purchasing power. } \\
\text { 18\% of shop owners respondents were } \\
\text { forced to change the type of goods they } \\
\text { used to sale to be adequate to the new } \\
\text { situation. } \\
\text { Also, the school demolition affected } \\
\text { negatively the student's parents; they were } \\
\text { forced to send their children to distant } \\
\text { schools, which was reflected on the } \\
\text { increasing of transportation fees, or to pay } \\
\text { for nearby private schools. }\end{array}$ \\
\hline Fonctional & $\begin{array}{l}\text { Because of its central location in the } \\
\text { downtown. } \\
\text { The school served the largest number of } \\
\text { students in different areas of the city, After } \\
\text { demolition, several schools were unable to } \\
\text { play that role, either because of their } \\
\text { location or the lack of adequate buildings. }\end{array}$ \\
\hline & Use Value \\
& & $\begin{array}{l}\text { The school had special importance for the } \\
\text { local community, all social events created } \\
\text { collective memory for the people, it had the } \\
\text { only play yard, it had the only theatre in the }\end{array}$ \\
\hline & Memory & \\
& &
\end{tabular}




\begin{tabular}{|l|l|l|}
\hline & & $\begin{array}{l}\text { city, which made it the gathering place for } \\
\text { all important events in the city; such as } \\
\text { football games, king Hussain speech, } \\
\text { famous singers, etc. }\end{array}$ \\
\hline Emotional & $\begin{array}{l}\text { Sentimental } \\
\text { value }\end{array}$ & $\begin{array}{l}\text { Emotional relationship: During the } \\
\text { interviews, many words carried a lot of } \\
\text { nostalgia and passion coupled with a deep } \\
\text { sense of loss for the school. The interviews } \\
\text { described the school as the "mother" } \\
\text { several times, and "like home" or "as my } \\
\text { home was demolished". These expressions } \\
\text { indicates that school had meant a lot to } \\
\text { many of As-Salt city people in their youth. }\end{array}$ \\
\hline Spatial & $\begin{array}{l}\text { Central } \\
\text { location in } \\
\text { the }\end{array}$ & $\begin{array}{l}\text { Since the school was located in the centre } \\
\text { of the city, it served a large part of the local } \\
\text { Domnuntown } \\
\text { neighborhoods, either walking or using } \\
\text { transportation that are in the middle of the } \\
\text { city. Directorate of Education tried to } \\
\text { distribute thestudents to other surrounding } \\
\text { schools in other places, but it didn't work } \\
\text { efficiently, many problems affected people. } \\
\text { [38]-[41]. } \\
\text { Most of students parents (72\%) expressed } \\
\text { their dissatisfaction for demolishing. They } \\
\text { consider that the central location of the } \\
\text { school was close to all the inhabitant } \\
\text { mountains and surrounding areas, for its } \\
\text { easy access on foot. The school } \\
\text { demolishing forced them to enroll their } \\
\text { children in the suburban areas, that needs } \\
\text { transportation, or to enroll them in private } \\
\text { schools in the same residential area. In both } \\
\text { cases the result was an additional economic } \\
\text { cost on the parents. It was an important } \\
\text { landmark of the city memory. }\end{array}$ \\
\hline Architectural \\
ppirit of the & Architectural \\
Language & $\begin{array}{l}\text { The International style with the modern } \\
\text { architectural language of the school was } \\
\text { presented by the horizontal openings and } \\
\text { obvious structural module system. }\end{array}$ \\
\hline Genius locai & $\begin{array}{l}\text { A special relationship between the function } \\
\text { as football yard and a theatre with the place } \\
\text { and with the local community, that gave the } \\
\text { school a spirit for them. }\end{array}$ \\
\hline
\end{tabular}

\section{B. Survey Findings}

Project interviews result show how randomless decisions had been taken away from community needs. The only benefit of the project was beautification of the heritage city center by tiling and cleanning buildings elevations.

The main problem in developing countries is that decisions are not based upon the community needs.

\section{1) The priorities of as-salt rehabilitation project vs. the local community needs}

As mentioned earlier, the rehabilitation project aims to replace the demolished areas, by a big yard, few shops, and services (Fig. 10,11). The demolition has been taken place in 2007, while the new construction started in 2013. Meanwhile, the vacant site during these six years was used by the local community as a central car parking for the downtown. Around 500 cars accomodated the demolished empty area (Fig. 12).

As the construction at 2013 began the old problem of providing enough car parking returns; it was noted that double-car parking, in the surrounding streets, increased; adding to the problem of the existing traffic jam; unfortunately the new project has only 170 car parkings. From the interviews, the first priorety for $(82 \%)$ of the community was to solve the traffic jam, followed by (63\%) to have enough car parking in the historical downtown (Fig. 13). The findings show that $(58 \%)$ of people come to the historical downtown by their own cars, only (20\%) come by buses. (Fig. 15) explains the high ratio of "solving the traffic Jams" as the first priority for the community, followed by" creating car parking spots in the downtown", as second priority.

The interviews show that the local community was not satisfied by the new yards in the rehabilitation project; they considered them as an "inappropriate", that yards became occupied by gangs and unemployed youth; the school yards that had been controlled earlier by school principals, are replaced by a site with out control activities. The participant in the interviews agree that the new situation doesn't fit socially with the conservative nature of As-Salt people.

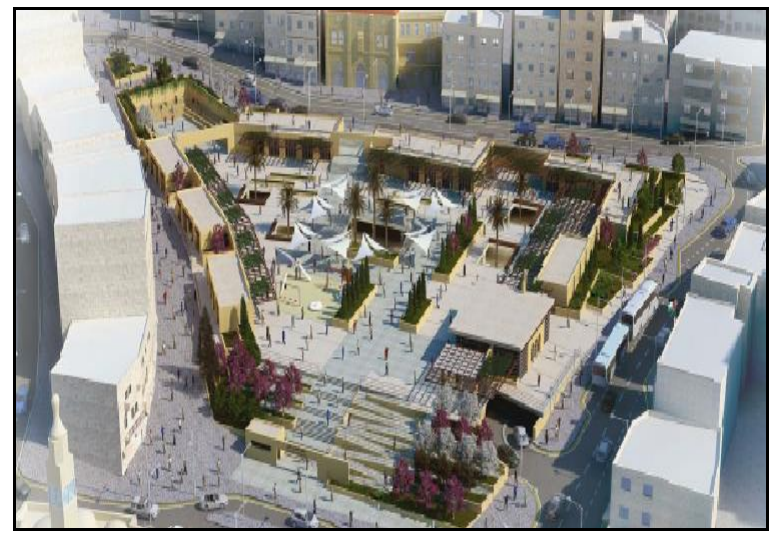

Fig. 10. The proposal design in the triangular area instead of the school and the commercial buildings. Source: As-Salt Municipality, 2014.

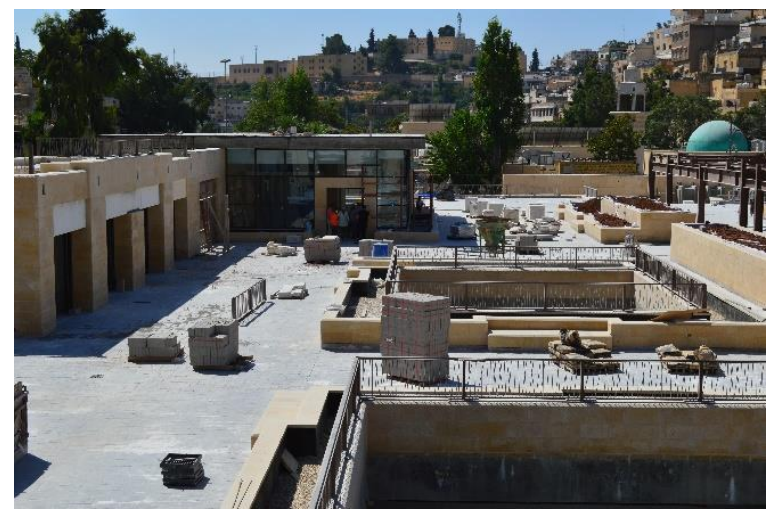

Fig. 11. The new design under construction. Source: As-Salt Municipality, 2019

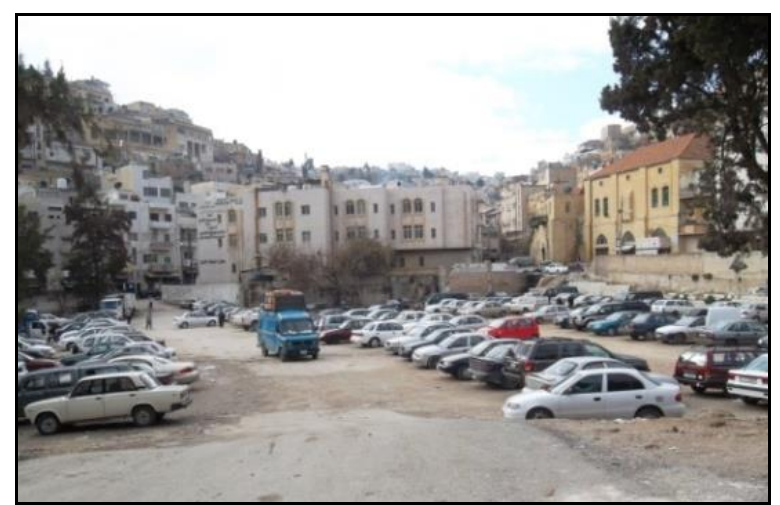

Fig. 12. Developing area after demolition, used as car parking by local community. Source: Author, 2013.

These results lead us to question the real benefit of such projects and if they realy meet the community needs, beside 
questioning the real reason of cunducting these projects, and if they are in any way related to the community needs or if they are allowed to share in decision making.

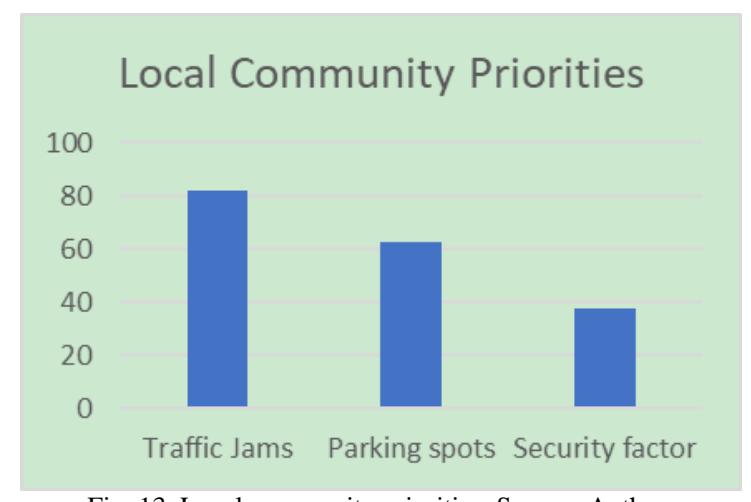

Fig. 13. Local community priorities. Source: Author.

\section{People Accsess to the downtown}

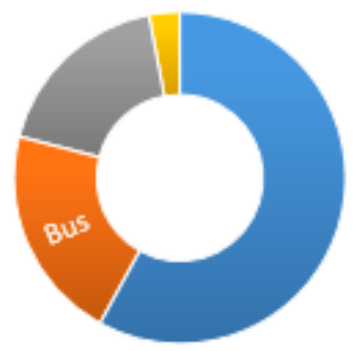

private car Bus Walking Taxi

Fig. 14. Site Access for local community. Source: Author.

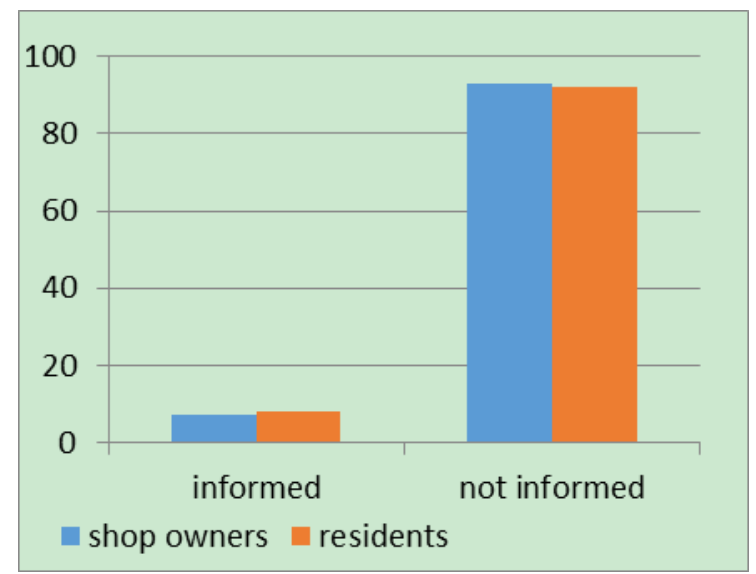

Fig. 15. Public informing. Source: Author.

\section{2) Public participation}

The findings show that $(92 \%)$ of the respondents didn't know about the project, they were not informed about its existence, and had not been asked about their opinion before the project implementation, not to say, they were asked to be a decision makers.

\section{a) Local community satisfaction}

The findings of community respondents show that the rejection rate for the rehabilitation project and the demolition of the school is (82\%) of the sample (Fig. 16). Which is explained by: a- the rehabilitation project dosen't meet the community needs, b- the new project decreased the economical power, c- that the rehabilitation project affected the collective community memories, and d- the new project didn't serve the community functinally.

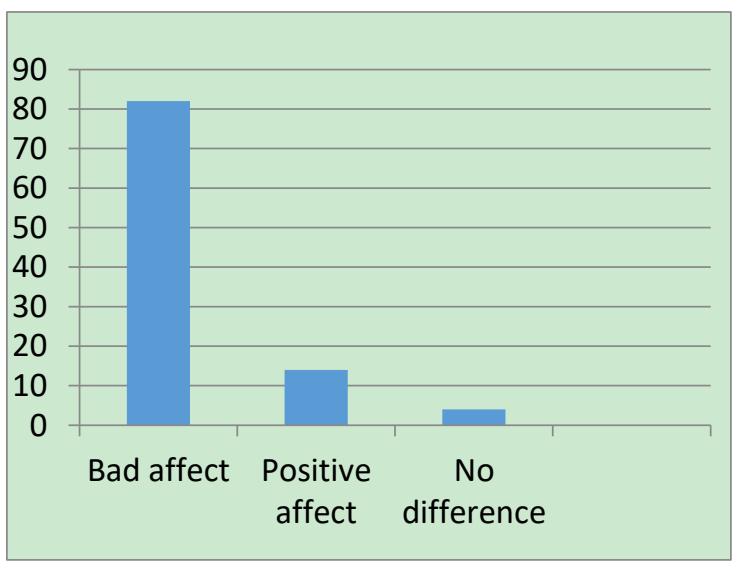

Fig. 16. Community opinion in school demolition. Source: Author.

\section{3) Beautification}

The findings show that the community was satisfied about the rehabilitation project due to only one issue, that is the improvement of the external appearance;(77\%) of community was satissfied with tiling, cleaning old dirty stone elevations, unifying shop signs, furnituring, and the whole situiation which means the local community was satisfied about the beautification of the project (Fig. 17).

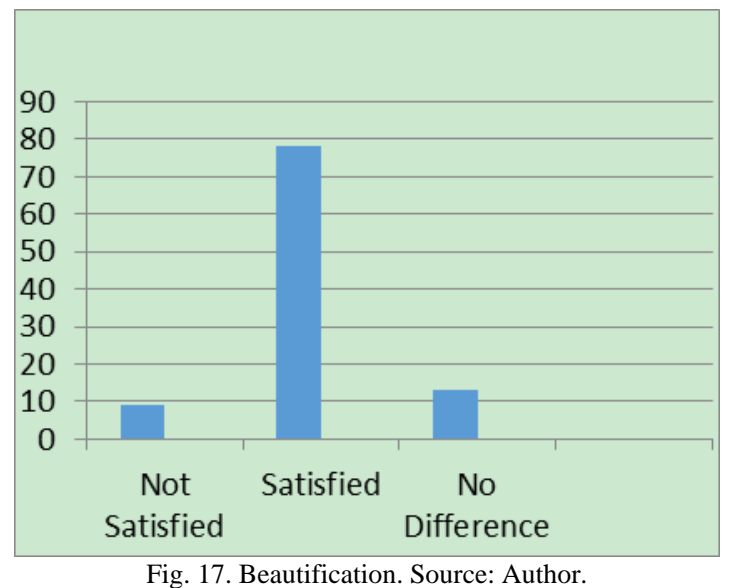

\section{CONCLUSIONS}

The results of the study show that the rehabilitation project in the historical downtown of As-Salt city didn't fit to community needs due to number of reasons related to their economic, transportation, and spiritual needs.

The community were not informed, beside, they were not share in decision making. Very few countries in the Arab world and developing countries have institutions that are concerned with Modern Heritage that is related to community spiritual needs. The advanced countries have recognized its importance and established some evaluation criteria for conservation modern heritage buildings. Unfortunately, Jordan lacks the recognition, protection, regulation, of Modern Heritage conservation.

This study tries to establish an evaluation criteria of 
Modern Heritage buildings in Jordan, in order to stop the current randomness in demolishing modern heritage buildings instead of protecting them.

Al-Khayyam Restaurant and Oqba bin Nafi School buildings, were suitable examples of demolishing modern buildings with their important values. If such buildings had undergone an evaluation process, they would undoubtedly have been classified as important Modern Heritage buildings, then it would have been preserved, restored and reused within the rehabilitation project context, instead of demolition. Therefore, these buildings should be documented virtually to stay in the community memory.

The findings of the study show that modern heritage buildings demolition affected negatively the city's memory. Modern heritage buildings in a city express the history of the city, any demolition may affect city history, just like deleting a chapter of a history book. Any modern heritage building could maintain it self more than 50 years, deserve to be evaluated and concidered for protection.

1) The results of this study show that the demolition of Oqbq bin Nafi school building had a negative impact on the economic situation of the downtown shop owners and site residents. This situation is contradicting the economic empowerment theory that asks to maintain sustainable conservation to heritage sites.

Donors are seeking to improve the conditions in the developing countries through their projects. Indeed, that was not reflected on the third tourism project in As-Salt city developing project.

The results of the study assured the results of other studies in Arab world (Khirfan, Luna, and Basma Momani, 2011); (Abu Al-Hija, 2011) (Daher, 1999) that assured that most of developing projects in the Arab world are just emphasizing the beautification dimensionmostly; they don't take into account the community development, and its economic, social and emotional needs, in the heritage sites developing.

2) One of the important results of the study show that the new project in As-Salt city, didn't match the community needs and their priorities; and while such element should be one of the project goals, The new project had just focused on creating big yards, tiling, furnishing and polishing old stones, without achieving the community priorities like solving traffic jam, or providing enough parking spots in the downtown, while neglecting social considerations; in this way the demolished land became a gathering spot for gangs and unemployed people.

This paper emphasises the involvement of all stakeholders such as residents and business owners in the decision making process regarding urban and architectural conservation projects. To insure a win-win outcome. The absence of public participation is reflected directly on the dissatisfaction of the community.

Sustainability is other important neglected aspect. It is unsustainable process to demolish good structured modern buildings in the developing projects, which could be sustained, and maintained the older heritage site.

\section{RECOMMENDATIONS}

Jordan acts as a model for developing countries that lacks of the regulations to recognize and protect Modern Heritage sites. A national plan is needed, on the level of governorates and minicipalities to list and evaluate modern heritage buildings and to have a plan to conserve such buildings.

Schools of architecture can help in the documentation process to establish an archive Modern Heritage buildings.

This decumentation can be done by applying and establishing criteria for modern heritage buildings, and creating regulations in accordance to the international rules, such as UNESCO and DOCOMOMO.

The communities and decision makers should be aware that demolition of modern heritage buildings would erase an important stage of city memory.

The paper recommends the including of social and economic experts, planners and architects in the project study team, to avoid unaccounting effects of these projects.

The study also considers that public participation is very important for successful rehabilitation projects.

It is notable that development projects should be oriented to community needs, and to have comprehensive studies and funding, before implementation, so as to avoid leaving an urban vacuum that reflects negativly on local community of the city.

It is recommended the documentation of demolishing processes of Modern Heritage buildings such as Uqba bin Nafe school and reconstruct them by different tools like vertual reality.

\section{CONFLICT OF INTEREST}

The authors declare no conflict of interest.

\section{REFERENCES}

[1] T. H. M. Prudon, Preservation of Modern Architecture, Chichester, U.K.: Wiley, 2008

[2] J. Loach, "Why we have to protect our modern buildings," 2009.

[3] F. Grementieri, "The preservation of nineteenth and twentieth-century heritage," World Heritage Papers 5, UNESCO World Heritage Centre, 2003.

[4] J. Jokilehto, "Modern built heritage as world heritage," The International Day for Monuments and Sites, Moscow, 2006.

[5] M. Kuipers, "Modern heritage: Identification, assessment, and interpretation," A Colloquium to Advance the Practice of Conserving Modern Heritage, Getty Conservation Institute, 2013.

[6] S. Uskokovic, "The concept of modern heritage values - An important aspect of urban heritage management," presented at International heritage Conference: Our Modern: Reappropriating Vulnerable 20th Century Heritage, Tokyo, Japan, 2013.

[7] International Committee for Documentation and Conservation of Buildings, Sites and Neighbourhoods of the Modern Movement.

[8] Docomomo International, JSTOR, December 2011.

[9] ICOMOS Action Plan on 20th Heritage: 2004, Japanse Survey Data.

[10] J. Widodo, "Current state of modern Asian architecture discourse and networking," Journal of Architectural Education, vol. 63, issue 2, pp. 79-81, March 2010.

[11] Conservation Perspective, Conserving Modern Architecture, The GCI Newsletter, vol. 28, no. 1, 2013.

[12] ICOMOS International Scientific Committee on Twentieth-Century Heritage, Madrid Document: Approaches for the Conservation of Twentieth-Century Architectural Heritage, 2011.

[13] S. Macdonald, "Modern matter: Breaking the barriers to conserving modern heritage," Conservation Perspectives, The Getty Conservation Institute, 2013.

[14] J. A. Qadi, "Cities and neighborhoods of the end of the nineteenth century and the beginning of the twentieth century in the south of the Mediterranean: heritage whom and why?" in Proc. the Fourth Conference of the Arab Architects Association: Aleppo between Heritage and Contemporary, 2006, p. 137. 
[15] M. Al-Shomali, "Analytical study for the criteria of heritage city center's development projects, case study: As-Salt City Center development project," Ph.D. Thesis, Damascus University, 2016.

[16] World Heritage Reports 12: The State of World Heritage in the Asia-Pacific Region, UNESCO WHC Publishing, Paris, 2003.

[17] K. Normandin and M. Susan, "A colloquium to advance the practice of conserving modern heritage," Los Angeles, California: The Getty Center, March 6-7, 2013.

[18] U. Jokilehto, The History of Conservation, 2nd ed., Abingdon, UK: Routledge, 2016.

[19] R. Ores and S. Haraguchi, "Identification and documentation of modern heritage," World Heritage Papers 5, UNESCO World Heritage Centre, 2003.

[20] UNESCO, "Criteria of selection," Modern Heritage Program, World Heritage List, 2005.

[21] Congress on the European Architectural Heritage, October 21-25, 1975.

[22] S. Gang et al., "Weights of the value assessment indicators in integrated conservation of modern architectural heritage," Journal of Applied Sciences, vol. 14, no. 6, pp. 580-585, 2014.

[23] S. Uskokovict, "The concept of modern heritage values - An important aspecs of urban heritage management," presented at mAAN the 6th Internationl Conference, Tokyo, Japan, 2006.

[24] N. Gultekin, "Evaluation of the conservation of modern architectural heritage through Ankara's public buildings," IOP Conference Series: Materials Science and Engineering, vol. 245, issue 8, p. 082046, 2017.

[25] Z. Yelmaz, "Conservation of Modern heritage place: "Carsi"- the commercial coreof middle east Technical University (METU)," Master thesis, MEUT, Turkey, 2018.

[26] S. M. Zancheti and J. Jukka, "Values and urban conservation planning: Some reflections on principles and definitions," Journal of Architectural Conservation, vol. 3, issue 1, pp. 37-51, 1997.

[27] Burra Charter. [Online]. Available: australia.icoms.org.

[28] J. Ruskin, The Seven Lamps of Architecture, New York, NY, USA: Dover Publication, 1989.

[29] K. Lynch, The Image of the City, Cambridge, MA, USA: MIT press, 1960.

[30] A. A. Al-Hija, Methods and Standards for the Protection of Architectural and Architectural Heritage Studies and Practical Experiences, Philadelphia University Publications, 2011.

[31] L. Khirfan and B. Momani, "Urban environment in Jordan, evaluation for associated urban planning," Waterlow University, 2011.
[32] A. Nammari and Fatima, "The preservation of vernacular architecture in Jordan: Development chances lost," US/ICOMOS, 2003.

[33] T. Heath, T. Oc, and S. Tiesdell, Revitalizing Historic Urban Quarters, 3rd Ed., 2001.

[34] R. Daher, "Gentrification and the politics of power, capital and culture in an emerging Jordanian heritage industry," The Traditional Dwelling and Settlement Review, vol. 10, no. 11, pp. 33-45, 1999.

[35] CSBE, Center of the Studying of Built Environment, Jordan, 2013.

[36] As-Salt Muncipility Publications, Salt Developing Heritage City Center Tourism Project, 2006.

[37] As-Salt Muncipility, Interview with Dr. Abdelelah Jaghbir, the last director of Oqba School, Sep. 2013.

[38] Personal Interviews with Parents of Oqba bin Naf' School Students, 2014.

[39] Interview with Eng. Ibrahim Amin, conducted by author, 2014.

[40] Interview with Sheikh Amin Kilani, who was born in 1926, conducted by author, 2015 .

[41] Interview with Mrs Nimat Atiyat, conducted by author, 2013.

Copyright $\odot 2020$ by the authors. This is an open access article distributed under the Creative Commons Attribution License which permits unrestricted use, distribution, and reproduction in any medium, provided the original work is properly cited (CC BY 4.0).

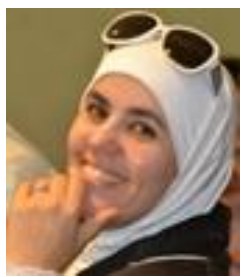

Maisa Ali Al-Shomali was born in Amman, Jordan, 1969. She received the bachelor and master's degrees from Jordan university in architectural design in 1991 and 2001, and $\mathrm{PhD}$ in urban design \& planning in heritage cities, Damascus University 2016/ Syria.

Currently, she is a professor in architectural department in Al-Balqa Applied University (BAU). She also works as a consultant in architectural design and conservation in consultation companies. She is a curriculum designer for technical programs driven by market, trained in Canada and worked for twinning programs between BAU and Canadian institute.

She is awarded by Arab women engineers from Arab Engineers Union for linking between academia and industry. She is an elected member in the central board of architectural department/ Jordan Engineering Association, and a member of the National Committee for Conserving urban heritage in Jordan.

She is interested in Jordanian heritage sites documentation, and has many publications and a book in this field. 